\title{
Variation in floristic and trait composition along environmental gradients in the herb layer of temperate forests in the transition zone between Central and SE Europe
}

\author{
Janez Kermavnar • Lado Kutnar • Aleksander Marinšek
}

Received: 19 May 2021 / Accepted: 1 November 2021/Published online: 10 November 2021

(C) The Author(s) 2021

\begin{abstract}
Species- and trait-environment linkages in forest plant communities continue to be a frequent topic in ecological research. We studied the dependence of floristic and functional trait composition on environmental factors, namely local soil properties, overstory characteristics, climatic parameters and other abiotic and biotic variables. The study area comprised 50 monitoring plots across Slovenia, belonging to the EU ICP Forests monitoring network. Vegetation was surveyed in accordance with harmonized protocols, and environmental variables were either measured or estimated during vegetation sampling. Significant predictors of species composition were identified by canonical correspondence analysis. Correlations between plant traits, i.e. plant growth habit, life form, flowering features and CSR signature, were examined with fourth-corner analysis and linear regressions. Our results show that variation in floristic composition was mainly explained by climatic parameters (mean annual temperature, mean annual precipitation), soil properties $(\mathrm{pH})$ and tree layer-dependent
\end{abstract}

Communicated by Thomas A. Nagel.

J. Kermavnar $(\bowtie) \cdot$ L. Kutnar · A. Marinšek Department of Forest Ecology, Slovenian Forestry Institute, Večna pot 2, 1000 Ljubljana, Slovenia e-mail: janez.kermavnar@gozdis.si

A. Marinšek

Higher Vocational College for Forestry and Hunting,

Ljubljanska cesta 2, 6230 Postojna, Slovenia light conditions. Trait composition was most closely related with tree layer characteristics, such as shadecasting ability (SCA, a proxy for light availability in the understory layer), tree species richness and tree species composition. Amongst soil properties, total nitrogen content and soil texture (proportion of clay) were most frequently correlated with different species traits or trait states. The CSR signature of herb communities was associated with tree layer SCA, soil $\mathrm{pH}$ and mean annual temperature. The floristic composition of the studied herb-layer vegetation depended on temperature and precipitation, which are likely to be influenced by ongoing climate change (warming and drying). Trait composition exhibited significant links to tree layer characteristics and soil conditions, which are in turn directly modified by forest management interventions.

Keywords Vegetation-environment relationship . Floristic composition $\cdot$ Life-history traits $\cdot$ Herbaceous species $\cdot$ Slovenia

\section{Introduction}

Herb-layer vegetation harbours the highest diversity of vascular plant species in temperate forests (Gilliam 2007; Thrippleton et al. 2016). Although not directly targeted during forest management interventions, this forest stratum plays a key role in the functioning of 
forest ecosystems (Landuyt et al. 2019). It may serve as a good ecological indicator and its species composition results from a complex interplay between numerous environmental drivers and spatiotemporal resource gradients (McEwan and Muller 2011; Sipoš et al. 2020). Identifying the ecological determinants of community composition has become a crucial step towards gaining a better understanding of how forest vegetation will respond to the challenges imposed by global environmental change, e.g. increasing $\mathrm{CO}_{2}$ levels, nutrient deposition leading to either eutrophication or acidification and altered disturbance regimes (Suding et al. 2008; Amatangelo et al. 2014; Dalle Fratte et al. 2019).

Temperate forest ecosystems currently cover around $16 \%$ of the global forest area (Hansen et al. 2010). They account for a wide variety of forest types, including thermophilous deciduous forests in Mediterranean subzones (Franklin 1988). Temperate forest understories are inhabited by plant species with distinctive life-history strategies that manifest as functional traits adapted to local environmental conditions (Durak and Durak 2021). Forest understory plant species vary in growth and life form, leaf lifespan, phenology, the prevalence of clonal reproduction, successional status and the mechanisms of seed dispersal (Burton et al. 2020). In mature forest stands the closed tree layer canopy induces a strong filtering effect by limiting light availability at the forest floor. Species composition and diversity and the cover of herb-layer communities might be additionally filtered by other environmental stressors, such as low nutrient availability on silicate bedrock or a water deficit on drier sites (lower soil moisture and air humidity) (Catorci et al. 2011). Similarly, coldinduced stress at higher altitudes favours species with a notable degree of conservatism, e.g. smaller leaves and a shorter, rosette-forming stature. Survival, growth and reproduction in resource-limited conditions can be achieved by a broad spectrum of ecological strategies, spanning from long-living organisms (trees) to annual herbaceous species (Silvertown et al. 1993).

Plant functional traits are tightly linked to environmental factors (Terwei et al. 2016; Burton et al. 2017). In fact, species traits can inform us about the leading dimensions of morphological, phenological and physiological adaptations that enable species to persist in the forest herb layer (Candeias and Fraterrigo 2020).
For example, many typical forest species have evolutionarily developed the specific strategy of finishing their life cycle before canopy closure in the deciduous overstory (e.g. early spring ephemerals) (Muller 1978; Sercu et al. 2021). Other forest specialists (mainly late-successional, shade-tolerant herbaceous perennials confined to closed forest interiors and rarely found in other habitats, such as forest edges or canopy gaps; Brunet et al. 2011; Schmidt et al. 2014) start to grow and flower later in the season. Such temporal niche differentiation importantly contributes to species coexistence in forest understories. Forest plants can tolerate a low light environment and exhibit a distinct functional profile, e.g. higher specific leaf area, larger seeds and a variety of storage or clonal organs (Bierzychudek 1982; Durak and Durak 2021). Furthermore, according to the study of Marinšek et al. (2015), habitat specialists in mixed broadleaved deciduous forests have proven to thrive primarily at high altitudes and on colder, drier sites, and the age of first flowering is later than that of generalists. They also have a smaller seed diameter, lower leaf dry matter content, lower mean canopy height and higher specific leaf area than generalists (Marinšek et al. 2015). In terms of Grime's CSR theory (Grime 1977), late-successional forest understories are characterized by stress-tolerant or competitive species, whilst disturbances increase the ruderal component of the community-level CSR signature (Eler et al. 2018).

In this study, we set out to determine (1) which environmental variables most significantly impact the floristic composition of the herb layer and (2) how species' life-history traits and community CSR signature are related to environmental variables. Using systematically sampled vegetation data distributed throughout Slovenia, we hypothesized that the floristic and functional composition of herb-layer vegetation are linked to different environmental factors.

\section{Materials and methods}

Study area and vegetation sampling

The study was conducted in 50 different forest sites across Slovenia. Although Slovenia is a small country in terms of geographic extent, it exhibits very diverse natural conditions. The selected forest sites differed significantly in terms of geological bedrock, climate, 
soil type, tree species composition, stand structure and other abiotic and biotic factors. The study area extends from lowland forests below $200 \mathrm{~m}$ a.s.l. to highaltitude forests reaching almost $1,500 \mathrm{~m}$ a.s.1. The study area is characterized by a broad climatic gradient. According to the WorldClim database (Fick and Hijmans 2017), for the period 1970-2000 mean annual temperature ranged from 3.2 to $11.7{ }^{\circ} \mathrm{C}$ and mean annual precipitation ranged from 791 to $2499 \mathrm{~mm}$.

We present a brief overview of the main forest vegetation types in Slovenia (Fig. 1), which is geographically and ecologically in the transition zone between Central and SE Europe. Located at the intersection between the Mediterranean, Alpine and continental climatic regimes, Slovenia exhibits great climate variability and can be divided into six phytogeographic regions (Wraber 1969): Alpine, Pre-Alpine, Dinaric, Pre-Dinaric, Sub-Mediterranean and Sub-Pannonian. The riparian forests, primarily comprising lowland woodlands located within the scope of larger streams and bodies of standing water, are mainly dominated by willows (Salix sp.), alders (Alnus glutinosa, A. incana), ashes (Fraxinus excelsior, F. angustifolia) and pedunculate oak (Quercus robur). In the hilly/submontane areas above floodplain and riverine forests, mixed forests of sessile oak (Quercus petraea) and European hornbeam (Carpinus betulus) are the predominant forest type. Most of the mid-altitude mountain areas are covered by forests formed by European beech (Fagus sylvatica), with admixtures of noble broadleaves (e.g. Acer pseudoplatanus, Fraxinus excelsior, Ulmus glabra, Prunus avium) and conifers (Abies alba, Picea abies). In the Alpine region (which encompasses the Julian Alps, Karavanke Mountains, Kamnik-Savinja Alps and Pohorje Mountains), various European beech forests mixed with Norway spruce (Picea abies), silver fir (Abies alba) and European larch (Larix decidua) reach the timberline up to the belt of the dwarf mountain pine (Pinus mugo). Scots pine (Pinus sylvestris) forests can be found throughout the country on acidic and nutrient-poor soils, but also on mixed and carbonate (dolomite) bedrock with shallow soils. Minor areas of Austrian pine (Pinus nigra) forests grow on extreme sites with a warmer microclimate. The Sub-Mediterranean region (positioned in the southwestern and western part of Slovenia with a Sub-Mediterranean climate) is covered with forest and shrubby vegetation of thermophilous broadleaf species (e.g. Ostrya carpinifolia, Fraxinus ornus, Sorbus aria, Quercus cerris, Q. pubescens). A similar type of forest is also present all over the country on sunexposed, south-facing slopes with predominant limestone and dolomite bedrock. The described natural forest types are intersected by numerous forms of secondary and other forest communities (often characterized by even-aged stands with a homogeneous structure), which are a consequence of managementmoderated tree species composition and related abiotic (edaphic) conditions (Kutnar et al. 2012; Bončina et al. 2021).

For the study we chose forest stands where a monitoring plan was established as a part of the ICP network (De Vries et al. 2000). Thirty-nine plots belong to the Level I scheme and 11 plots are designed for the Intensive Monitoring Programme (Level II). Level I plots are systematically distributed in a $16 \mathrm{~km} \times 16 \mathrm{~km}$ grid across Slovenia (Kutnar 2011). Level II plots were established in 11 different locations, representative of the heterogeneity of Slovenian forest types (Urbančič et al. 2016; Kermavnar and Kutnar 2020). We collected plant community and environmental data in 50 monitoring plots of $400 \mathrm{~m}^{2}$ in size. All vascular plants in the tree (woody species with height $>5 \mathrm{~m}$ ), shrub (woody species taller than $0.5 \mathrm{~m}$ and shorter than $5 \mathrm{~m}$ ) and herb layer (all herbaceous species and woody species with height $<$ $0.5 \mathrm{~m}$ ) were recorded, following harmonized ICP protocols for ground vegetation sampling (Canullo et al. 2016). The abundance of each plant species was estimated based on a modification of Barkman's method (Barkman et al. 1964). Detailed information on the study area and the sampling design can be found in Kermavnar et al. (2021).

Environmental data

For each study plot, we collected data on soil properties, forest stand characteristics, climatic parameters and other environmental variables. Soils were sampled in each monitoring plot, according to the ICP methodology (Cools and De Vos 2016). Soil samples were taken for different layers distinguishing between organic soil layers $\left(\mathrm{O}_{\mathrm{f}}, \mathrm{O}_{1}, \mathrm{O}_{\mathrm{h}}\right)$ and mineral soil layers $(0-5 \mathrm{~cm}, 5-10 \mathrm{~cm}, 10-20 \mathrm{~cm}, 20-40 \mathrm{~cm}$ and $40-80 \mathrm{~cm}$ ). The following ecologically relevant variables were measured for soil samples from 


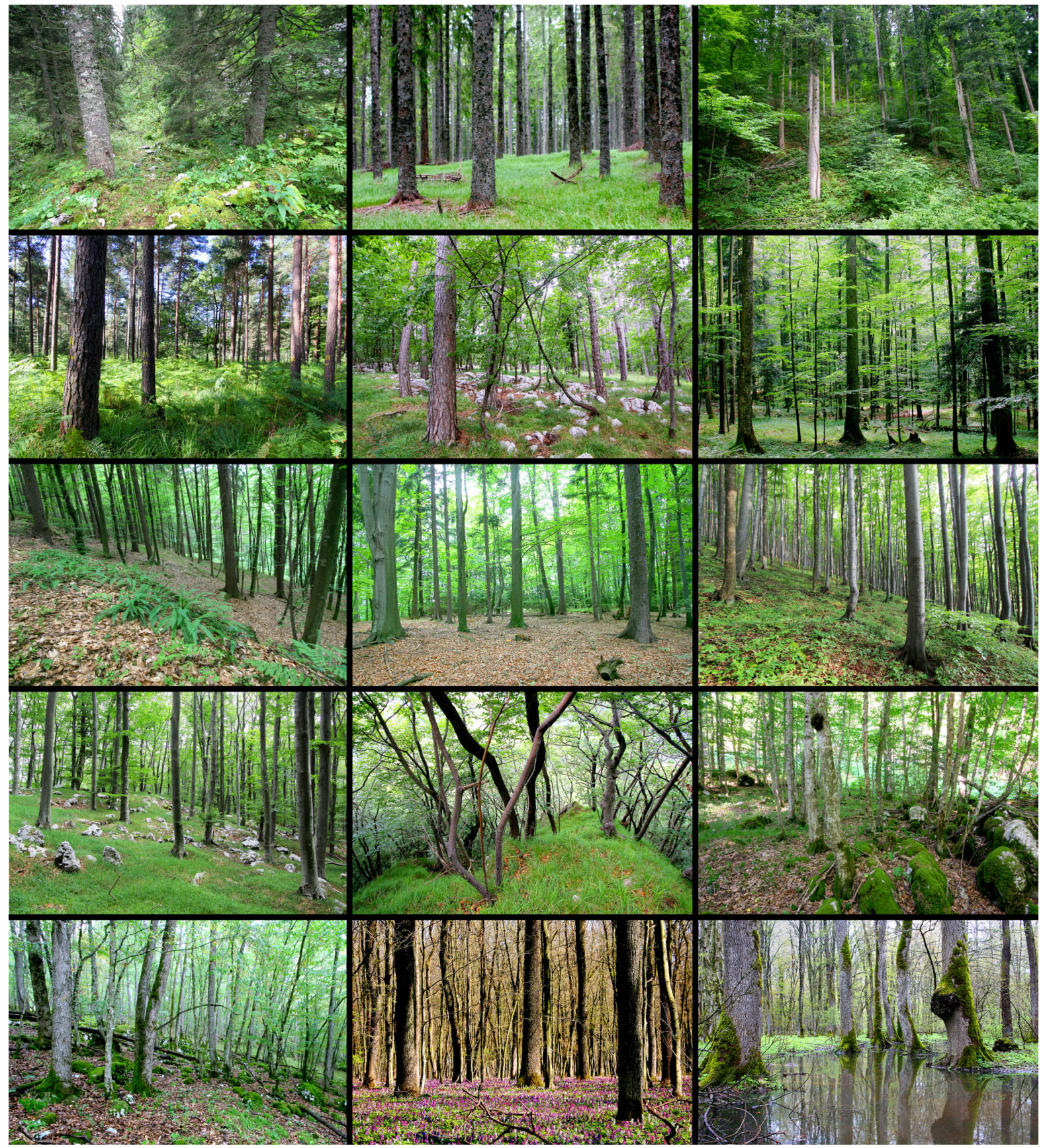

Fig. 1 Representative forest vegetation types in Slovenia (all photos: L. Kutnar)

different layers (Table 1): $\mathrm{pH}$ (measured in $\mathrm{CaCl}_{2}$ ), soil organic carbon (SOC, $\mathrm{g} / \mathrm{kg}$ ), total nitrogen content $(\mathrm{g} / \mathrm{kg})$, proportion of clay (derived from soil texture analysis) and soil moisture content (\%) (Kermavnar et al. 2021). The values were then averaged across layers to obtain single plot-level values. Tree layer characteristics were also considered: tree species richness, the proportion of broadleaves and tree layer shade-casting ability (SCA), which was calculated as weighted averages, using tree species relative abundances and shade production values (evaluated based on the leaf area index) provided by Leuschner and 
Table 1 List of selected 14 environmental variables used as predictors for herblayer vegetation composition

\begin{tabular}{llrrr}
\hline Variable & Unit & Min & Mean & Max \\
\hline Soil pH & Unitless & 3.6 & 5.0 & 6.7 \\
Soil organic carbon (SOC) & $\mathrm{g} / \mathrm{kg}$ & 357.5 & 530.9 & 1305.2 \\
Total soil nitrogen & $\mathrm{g} / \mathrm{kg}$ & 12.9 & 21.1 & 58.0 \\
Proportion of clay in the soil & $\%$ & 7.3 & 28.8 & 60.5 \\
Soil moisture & $\%$ & 3.3 & 6.8 & 17.6 \\
Tree layer species richness & Unitless & 1.0 & 4.7 & 10.0 \\
Proportion of broadleaves in the tree layer & $\%$ & 0.0 & 72.9 & 100.0 \\
Shade-casting ability (SCA) of the tree layer & Unitless & 0.9 & 3.6 & 5.0 \\
Mean annual temperature (MAT) & ${ }^{\circ} \mathrm{C}$ & 3.2 & 8.1 & 11.7 \\
Mean annual precipitation (MAP) & mm & 791.0 & 1473.3 & 2499.0 \\
Altitude & $\mathrm{m}$ & 160.0 & 650.9 & 1490.0 \\
Heat load index (Hi) & Unitless & -0.7 & 0.0 & 0.8 \\
Woody debris & $\%$ & 1.0 & 5.3 & 15.0 \\
Moss cover & $\%$ & 0.3 & 7.2 & 56.8 \\
\hline
\end{tabular}

Meier (2018). Low SCA values indicate relatively sparse canopy (e.g. Pinus sylvestris-dominated stands), whilst high SCA values denote dense canopy casting deep shade (e.g. Fagus sylvatica or Carpinus betulus-dominated stands). Two climatic parameters, mean annual temperature (MAT) and mean annual precipitation (MAP) were sourced from the WorldClim database (Fick and Hijmans 2017). The environmental matrix also contained data regarding plot altitude, heat load index (Hi) expressing the relative amount of heat received through solar radiation considering local slope aspect and slope steepness (Geiger 1966), the cover of woody debris (\%) and the cover of the moss layer (\%) on developed soil - both were visually estimated during the vegetation surveys. Fourteen environmental variables in total were obtained for each plot either from data collected in the field or from external sources (Table 1). Some additional information on the acquisition and/or calculation of environmental data is given in Kermavnar et al. (2021). The correlation matrix for explanatory variables can be found in the Supplementary materials (Appendix 1).

Functional traits data

Life-history traits for the recorded plant species were taken from the national flora (Martinčič et al. 2007). Data on plant growth habit (PGH; distinguishing between six growth habits using our own expert-based botanical knowledge derived from Martinčič et al.
2007), plant life form (PLF; Raunkiaer 1934) and the start, end and duration of flowering phenology (Martinčič et al. 2007) were collected. In addition, each species was characterized in terms of CSR ecological strategies, using the approach outlined by Pierce et al. (2017). Data on the C-, S- and R-score were taken from the PLADIAS open-source database (https://pladias.cz/en/; Chytrý et al. 2021). Information compiled on selected plant traits is presented in Table 2.

Data analysis

Variation in floristic composition between monitoring plots was examined with canonical correspondence analysis (CCA; ter Braak 1987). CCA is a unimodal ordination technique with the ordination axes constrained as linear combinations of environmental predictor variables (ter Braak 1987). We applied a manual forward selection procedure to select the main environmental variables, beginning with an interceptonly model. Model choice was made based on Akaike's information criterion as a measure of model quality. The significance of the final suite of constraints was determined using an ANOVA-like permutation test with 999 permutations. Interdependence between constraining variables was checked with a variance inflation factor. Species abundances were $\ln (x+1)$ transformed, and rare species (present only in one plot) with minor abundance were excluded beforehand. 
Table 2 Selected life-history and CSR traits for plant species

\begin{tabular}{|c|c|c|}
\hline Trait & Data type & Description \\
\hline $\begin{array}{l}\text { Plant growth habit } \\
\text { (PGH) }\end{array}$ & Nominal & $\begin{array}{l}\text { Six categories (trait states): fern, forb, graminoid, tree, shrub (including dwarf shrubs), woody } \\
\text { or semi-woody vine (Martinčič et al. 2007) }\end{array}$ \\
\hline $\begin{array}{l}\text { Plant life form } \\
\text { (PLF) }\end{array}$ & Nominal & $\begin{array}{l}\text { Five categories (trait states) according to Raunkiaer (1934): chamaephyte, geophyte, } \\
\text { hemicryptophyte, phanerophyte and therophyte (Martinčič et al. 2007) }\end{array}$ \\
\hline Onset of flowering & Ordinal & Start of flowering (month): $\min =$ January, $\max =$ September $($ Martinčič et al. 2007) \\
\hline End of flowering & Ordinal & End of flowering (month): $\min =$ March, $\max =$ December (Martinčič et al. 2007) \\
\hline $\begin{array}{c}\text { Duration of } \\
\text { flowering }\end{array}$ & Ordinal & $\begin{array}{l}\text { The difference between onset and end of flowering (months): } \min =\text { one month, } \max =12 \text { months } \\
\text { (Martinčič et al. 2007) }\end{array}$ \\
\hline C-score & Numerical & $\begin{array}{l}\text { Plant species score for C-strategy calculated based on leaf traits (described in Pierce et al. 2017): } \\
\min =0.0 \%, \text { mean }=37.4 \%, \max =90.9 \%\end{array}$ \\
\hline S-score & Numerical & $\begin{array}{l}\text { Plant species score for S-strategy calculated based on leaf traits (described in Pierce et al. 2017): } \\
\min =0.0 \%, \text { mean }=28.8 \%, \max =100.0 \%\end{array}$ \\
\hline R-score & Numerical & $\begin{array}{l}\text { Plant species score for R-strategy calculated based on leaf traits (described in Pierce et al. 2017): } \\
\min =0.0 \%, \text { mean }=33.8 \%, \max =95.0 \%\end{array}$ \\
\hline
\end{tabular}

To increase the interpretability of CCA outputs, all plots/sites were classified based on the tree layer species composition and parent material. First, we analysed the percentage cover of each tree species occurring in the tree layer. Species were then ranked with respect to their abundances, and the ratio between broadleaves and conifers was calculated. If the plot was dominated by a single tree species, it was classified as a monodominant stand (i.e. Fagus sylvatica and Picea abies in our dataset). If the tree layer was in favour of broadleaves other than Fagus sylvatica, it was classified into the group of other broadleaves. If the tree layer was in favour of conifers other than Picea abies, it was classified into the group of other conifers. Within this scheme, we also included geological criteria for plots dominated by Fagus sylvatica, as these communities depicted a wide forest soil and geological spectra. Furthermore, each plot was also classified based on the phytosociological typology of forest site types (Kutnar et al. 2012; Bončina et al. 2021). As a result, we distinguished between five different site groups: Fagus sylvaticadominated sites on carbonate bedrock (12 plots), Fagus sylvatica-dominated sites on non-carbonate bedrock ( 8 plots), sites dominated by other broadleaf tree species (15 plots), Picea abies-dominated sites (6 plots) and sites dominated by other coniferous tree species (9 plots). For each group we also identified herb-layer indicator species by implementing a statistical method proposed by Dufrêne and Legendre (1997).

Fourth-corner analysis (Dray and Legendre 2008) was employed to evaluate correlations between environmental variables and life-history traits. This analysis combines three matrices: table $\mathrm{R}$ (plots $\times$ environmental variables), table $\mathrm{L}$ (species $\times$ plots) and table Q (species $\times$ traits). In the case of a community CSR signature, the associations between the community-weighted mean (CWM; Lavorel et al. 2008) for C-score, S-score and R-score and environmental variables were examined with univariate linear regression models. The coefficient of determination $\left(\mathrm{R}^{2}\right)$ was used as a measure of goodness of fit.

Prior to CCA and fourth-corner analysis, environmental variables were checked for their distribution and in the event of a significant departure from normality, appropriate transformations were used. Each predictor was relativized to vary between zero and one, meaning that all explanatory variables were on the same scale. Significance was determined at $P=<0.05$ in all analyses, which were conducted in $\mathrm{R}$ statistical software version 3.5.2 (R Core Team 2018). The vegan package (Oksanen et al. 2019) was used for CCA, whereas the ade4 (Dray et al. 2020) and indicspecies (De Cáceres et al. 2020) packages were used for the fourth-corner analysis and indicator species analysis, respectively. 


\section{Results}

\section{Floristic composition}

Collectively, the environmental variables included in the final CCA model explained $15.6 \%$ of the variation in plant community composition. The constraining variables in the final model were mean annual temperature (MAT), mean annual precipitation (MAP), tree layer shade-casting ability (SCA) and soil pH (Fig. 2) in descending order of importance. The first and the second CCA axis explained $4.6 \%$ and $4.5 \%$ of the variation, respectively. MAT was most strongly correlated with the first axis $(r=-0.92)$, whereas MAP $(r=0.76)$, tree layer SCA $(r=0.49)$ and soil $\mathrm{pH}(r=0.58)$ exhibited a stronger correlation with the second CCA axis (Fig. 2).

Trait composition

A total of 28 associations (out of 196 possible) between life-history traits (trait states) and environmental variables were detected as significant $(p<0.05)$. Thirteen of them were positive and 15 were negative correlations (Fig. 3). Three environmental variables (mean annual precipitation - MAP, heat load index - Hi, woody debris cover) did not affect any of investigated life-history traits.

Forbs as a plant growth habit were positively influenced by soil $\mathrm{pH}$, total soil nitrogen and tree layer shade-casting ability (SCA). Graminoids showed a negative association with the proportion of broadleaves in the tree layer and tree layer SCA. Shrubs were positively correlated with the proportion of clay in the soil and moss cover but were negatively impacted by tree layer SCA. Tree layer richness increased the frequency/abundance of tree species in the herb layer (Fig. 3).

Chamaephytes as a plant life form exhibited a negative correlation with soil moisture. Hemicryptophytes were positively affected by soil organic carbon, soil nitrogen and altitude. In contrast, this life form was negatively affected by the proportion of clay in the soil, tree layer species richness and mean annual temperature. Phanerophytes showed the reverse pattern. These were positively associated with the proportion of clay, tree layer species richness and mean annual temperature but exhibited a negative correlation with soil nitrogen and altitude (Fig. 3).

In our dataset, phenological traits were most tightly linked to tree layer characteristics. The onset of flowering was negatively correlated with the
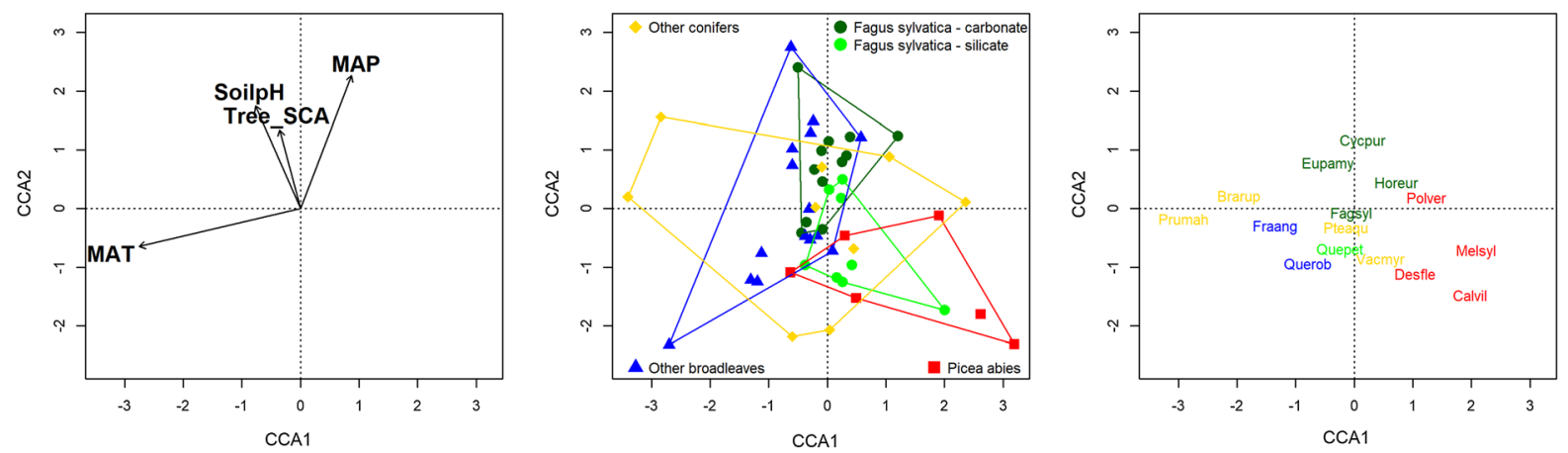

Fig. 2 Canonical correspondence analysis (CCA) diagrams showing the main dimensions of floristic variability in herblayer vegetation constrained by the first two CCA axes. Left panel: black arrows denote significant environmental variables (MAT - mean annual temperature, MAP - mean annual precipitation, SoilpH - soil pH, Tree_SCA - shade-casting ability of the tree layer). Middle panel: distribution of 50 monitoring plots/sites in the CCA ordination space. Plots were grouped in five groups based on tree layer species composition and parent material: Fagus sylvatica-dominated sites on carbonate bedrock (dark-green circles), Fagus sylvatica-dominated sites on non-carbonate (silicate) bedrock (green circles), sites dominated by other broadleaf tree species (blue triangles),
Picea abies-dominated sites (red squares) and sites dominated by other coniferous tree species (golden rhombuses). Right panel: indicator species in the herb layer for each site group. Species names are coloured according to the five groups (middle panel) and coded as follows: Cycpur-Cyclamen purpurascens, Eupamy - Euphorbia amygdaloides, Fagsyl - Fagus sylvatica, Horeur - Hordelymus europaeus, Quepet - Quercus petraea, Fraang - Fraxinus angustifolia, Querob-Quercus robur, Calvil - Calamagrostis villosa, Desfle - Deschampsia flexuosa, Melsyl - Melampyrum sylvaticum, Polver - Polygonatum verticillatum, Brarup - Brachypodium rupestre, Prumah - Prunus mahaleb, Pteaqu - Pteridium aquilinum and Vacmyr - Vaccinium myrtillus 


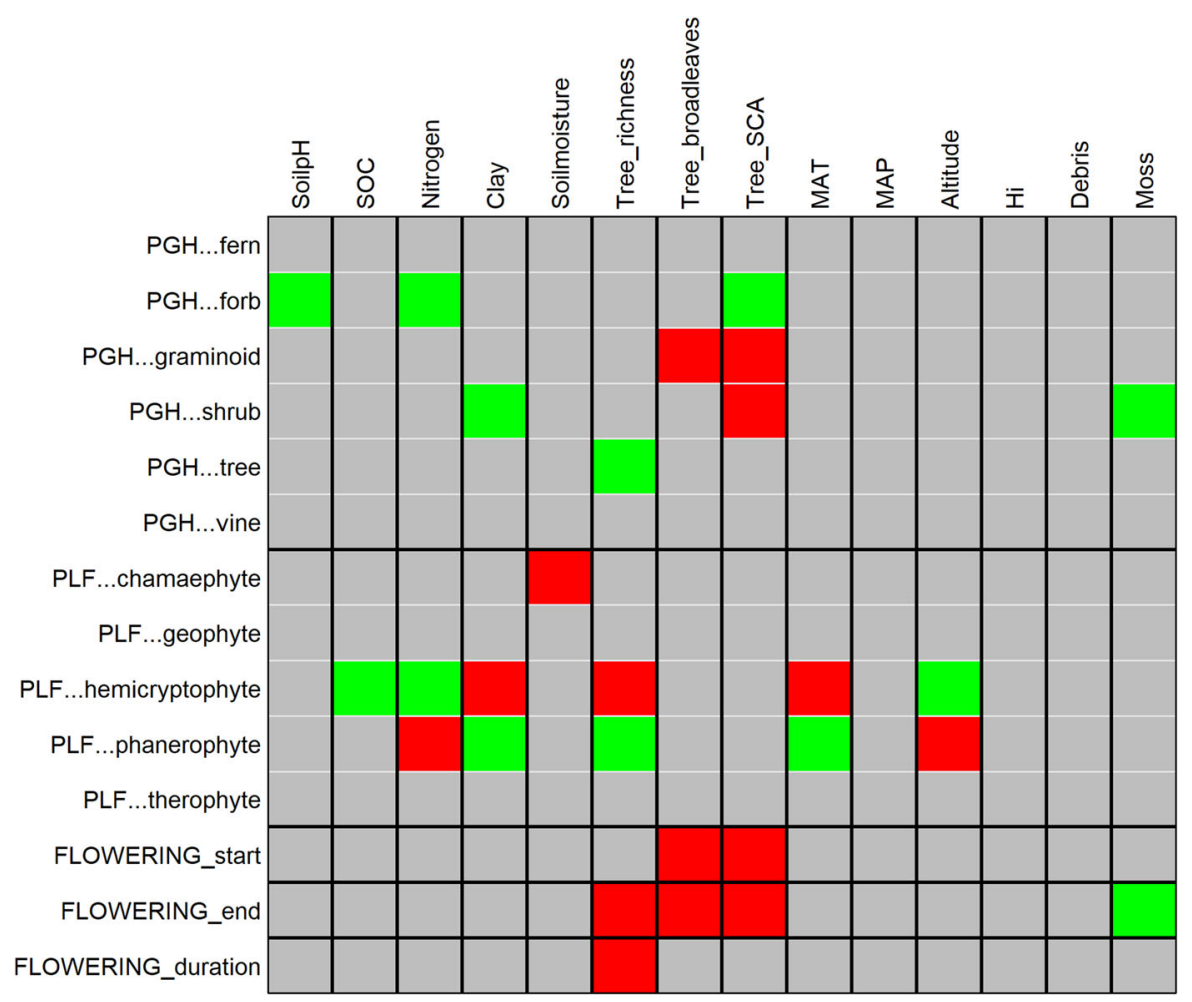

Fig. 3 Significant correlations between plant traits (trait states, in rows) and environmental variables (in columns) detected with fourth-corner analysis. Red colour denotes negative correlations and green quadrats are for positive correlations. PGH = Plant growth habit, PLF = Plant life form (Raunkiaer 1934),

proportion of broadleaves in the tree layer and tree layer SCA. The same was true for the end of flowering, which was also negatively correlated with tree species richness. This explanatory variable showed a negative correlation with the duration of flowering (Fig. 3).

The analysis of linear regressions between community-weighted means (CWM) of C-, S- and $\mathrm{R}$-scores and individual environmental variables showed four significant relationships (Fig. 4). The $\mathrm{C}$-score was positively related to tree layer SCA $\left(\mathrm{p}<0.05, \mathrm{R}^{2}=0.08\right)$. The community-level S-score decreased with increasing soil $\mathrm{pH} \quad(\mathrm{p}<0.05$, $\left.\mathrm{R}^{2}=0.11\right)$ and increasing tree layer SCA $(\mathrm{p}<0.01$, $\mathrm{R}^{2}=0.14$ ). The CWM of the R-score in herb-layer communities was negatively linked to mean annual precipitation ( $\left.\mathrm{p}<0.01, \mathrm{R}^{2}=0.20\right)$ (Fig. 4).
FLOWERING_start $=$ start of flowering $($ month), FLOWERING_end $=$ end of flowering (month), FLOWERING_duration = duration of flowering (months). For the names and definitions of environmental variables, see Table 1

\section{Discussion}

This study highlighted the environmental determinants of floristic and trait composition in assemblages of vascular plant species in the herb layer of temperate forests across Slovenia. The dominant factors which explained the floristic composition are similar to those reported by Leuschner and Lendzion (2009). Our results showed that floristic composition is driven by climatic parameters (mean annual temperature, mean annual precipitation), soil properties (soil $\mathrm{pH}$ ) and forest stand characteristics (tree layer SCA) regulating light availability at the forest floor. Light conditions were also an important environmental factor for herblayer composition in Hungarian temperate forests (Márialigeti et al. 2016) and light availability drives biodiversity changes in herb-layer communities across Europe (Depauw et al. 2019). Meaningful overstory influences on the herb and shrub communities of mature forests were confirmed in the studies of 

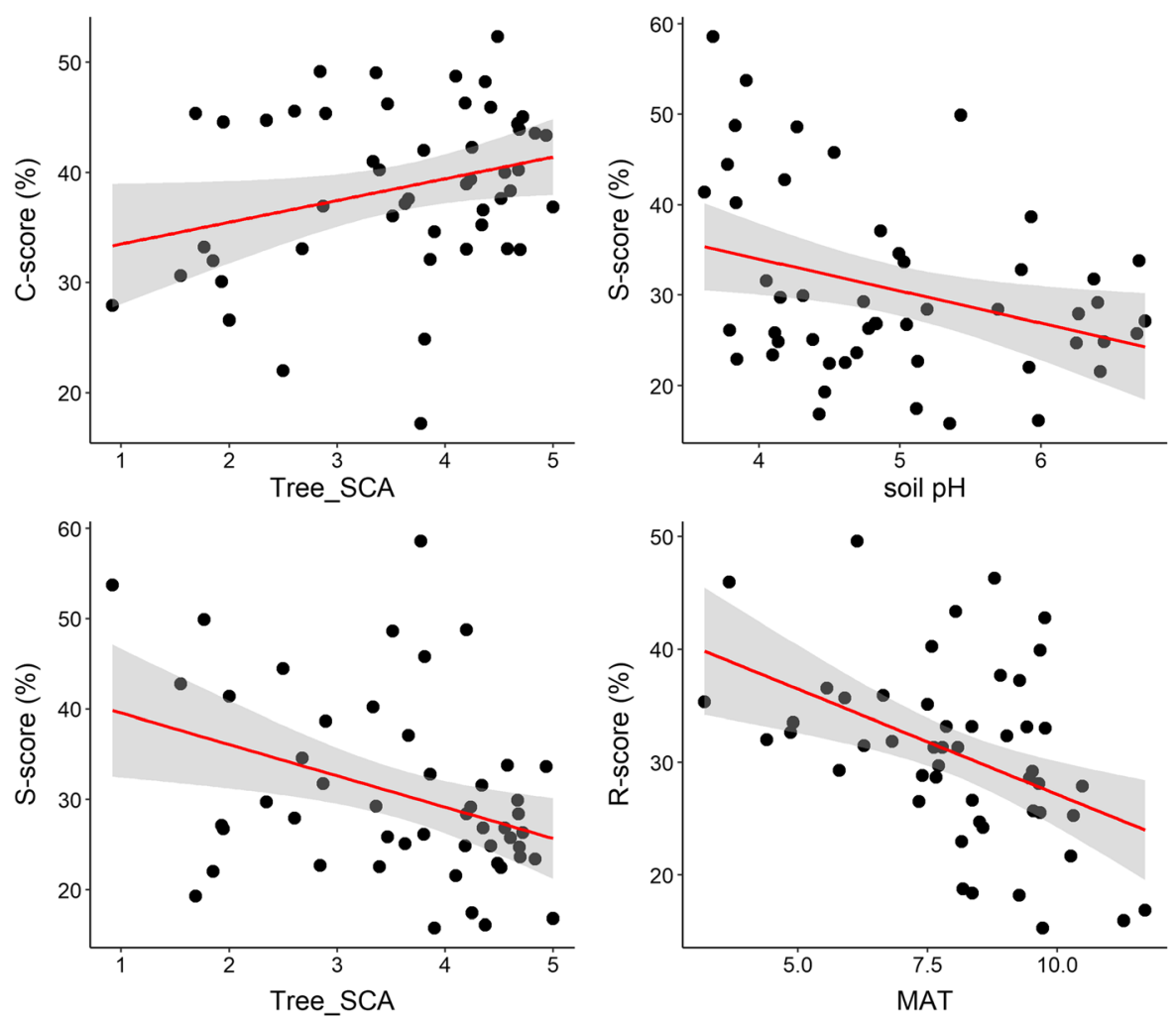

Fig. 4 Linear regression analysis between communityweighted mean of C- (C-strategists), S- (S-strategists) and R(R-strategists) scores (\%) and significant environmental

McKenzie et al. (2000) and Dölle et al. (2017). In our previous study (Kermavnar et al. 2021) we illustrated the complete absence of a climatic signal for herblayer species diversity (species richness, herb-layer cover and evenness). In contrast, the present results indicate the profound effect of climatic parameters on herb-layer species composition. Different aspects of plant community structure (composition vs. diversity) are thus affected by different environmental factors. Besides a strong influence of abiotic factors, biotic factors like dispersal ability, competition or herbivory can explain forest species distribution patterns on a finer spatial scale (Leuschner and Lendzion 2009).

The novelty of our approach lies in the parallel assessment of floristic and trait-based perspectives. Although taxonomic and functional components are often closely linked to each other, broadening the focus from taxonomy to functional traits is widely accepted (Terwei et al. 2016; Tardella et al. 2019). It is noteworthy, however, that some simple traits (yet easily available for the majority of species, e.g. plant variables: Tree_SCA $=$ shade-casting ability of the tree layer, soil $\mathrm{pH}$ and $\mathrm{MAT}=$ mean annual temperature. The grey ribbon around the curve indicates $95 \%$ confidence interval

life and growth form) allow fewer general conclusions, as plant ecologists seldomly integrate wholeplant traits in comparison to numerical traits describing the global spectrum of plant form and function (Durak and Durak 2021).

One issue worth discussing is covariation between selected environmental variables, which can greatly confound the interpretation of their real effects on species and trait composition. For example, tree layer composition and diversity are often linked to soil properties and climatic parameters. Forest soil properties, however, also depend on the dominant tree species, macroclimate and local topographic factors (Weigel et al. 2019). A reliable distinction between individual influences of different explanatory factors is thus difficult and (in)direct effects may be masked by myriad possible interactions amongst them. Interdependence between predictors could lead to some bias and accurate predictions might be even more complicated if forest management or legacy of past land use (trajectory of successional development) 
plays an important role in structuring herb-layer assemblages (Brunet et al. 2011; Depauw et al. 2019). Forest community composition is driven by environmental variables that are under the direct control of the actual silvicultural management (Tinya et al. 2021). Notwithstanding, based on the correlation matrix (Appendix 1), we assume that the degree of such confounding effects is rather low in our dataset. The highest correlations are found for variables within the same group of predictors than across predictor groups (e.g. soil parameters generally show a higher association with each other compared to the associations with the tree layer or climatic factors).

We selected a set of functional traits capturing the main axes of trait variation in forest herb-layer vegetation. Categorical traits such as plant life and growth forms have been shown to be a good surrogate for explaining the variability in key traits describing fundamental trade-offs between leaf economics, plant size and reproduction (Durak and Durak 2021). In our case, forbs, graminoids and shrubs were correlated with different soil properties and tree layer characteristics. These features of forest stands are impacted by management disturbances, as shown by Ramovs and Roberts (2005). The same environmental factors influenced plant growth habits in different ways. For example, most forest forbs benefited from the higher shade induced by dense tree layer closure, whilst graminoids exhibited the opposite pattern. Dölle et al. (2017) showed higher proportion of graminoids and shrubs in the sessile oak (Quercus petraea) stands compared to beech-dominated (Fagus sylvatica) plots. Improved light conditions support the expansion of plant species adapted to a high-light environment (Kermavnar et al. 2021). Many herb-layer communities in our coniferous plots experienced prominent domination of grasses with pervasive clonal reproduction abilities (some examples: Calamagrostis villosa and Deschampsia flexuosa in Picea abies forest, Sesleria autumnalis and Brachypodium rupestre in Pinus nigra forest, Molinia caerulea subsp. arundinacea in Pinus sylvestris forest; see Table 1 in Kermavnar and Kutnar 2020). The differential influence is even more evident for plant life form. The majority of environmental factors (except for SOC) that were positively correlated with hemicryptophytes induced negative control on phanerophytes and vice versa. Such patterns suggest excluding interactions between these two most abundant life forms in our dataset. Tardella et al. (2019) reported that topographic factors (altitude and slope aspect) induced strong environmental filtering which changed the relative abundance of herb-layer traits and functional richness of life forms in Sub-Mediterranean coppiced woods. In contrast, our results suggest that heat load index (combining both slope aspect and slope steepness) was not significant in predicting any of the dependent variables. This is likely because we analysed a broad spectrum of forest types across Slovenia rather than comparing communities on smaller (regional, local) spatial scale.

The flowering attributes (start, end and duration) of herb-layer species were exclusively associated with tree layer characteristics. The results indicate that herb-layer communities in deciduous forests are characterized by the early onset and short duration of flowering. Vernal geophytes are known for their adaptation of producing flowers before the deciduous overstory canopy develops and consequent light availability at the forest floor is reduced (Whigham 2004), reflecting phenological asynchrony between spring and summer plant species. This group of species also have a very short flowering period compared to other species and can be additionally differentiated in terms of some key functional traits related to leaf economics and plant size spectra (e.g. specific leaf area, leaf dry matter content, plant height, seed mass) (Durak and Durak 2021; Cubino et al. 2021). In addition, phenological traits of understory communities perhaps depend more on species (i.e. are species-specific) and not only on canopy closure or tree species composition.

CSR signature was associated with tree layer SCA, soil $\mathrm{pH}$ and mean annual temperature. Tree layer SCA (a proxy for light conditions) was the most important factor. This is in line with the study of Catorci et al. (2011), who found that the variation in trait data in the herb layer of Sub-Mediterranean forests was best explained by photosynthetically active radiation. Looking at the patterns for our plots, the C-score increased along the tree layer SCA gradient, suggesting that competitors are more abundant in shaded understory environments. Given that $40 \%$ of our plots were dominated by Fagus sylvatica shade-tolerant herbaceous species typically occurring in beech understory may have contributed to the observed trend. Beech forest species show a rather narrow spectrum of ecological niches (higher requirements 
for soil nutrients and moisture) and share similar functional traits associated with a competitive and/or stress-tolerant strategy but limited dispersal ability (Willner et al. 2009). Understories of broadleaved deciduous European forests (such as beech forests on non-acid soils or ravine forests) more commonly host species with acquisitive leaf economics (Cubino et al. 2021). Such a pattern can also be interpreted with respect to shade-tolerant competitive tree species (e.g. Fagus sylvatica) in the herb layer, facilitated by overstory seed sources. Herb layer in pure beech stands is often dominated by juvenile trees, mainly beech and competitive herbaceous species (Dölle et al. 2017).

Light availability was also decisive for the abundance of S-strategists. However, in contrast to the common belief that the main abiotic stress in forests is manifested in low light availability, we found that the S-score decreased along the tree layer SCA gradient. One possible explanation for the deviation from the prediction might be because our plots with high tree layer SCA values were characterized by higher soil $\mathrm{pH}$ (the correlation can be recognized on Fig. 2), e.g. different beech forests on carbonate bedrock. In addition, environmental constraints often do not exert selection on single traits but instead exert selection on multiple traits simultaneously (Candeias and Fraterrigo 2020). We can conclude that the main environmental stress within the studied dataset was induced by low soil $\mathrm{pH}$, whilst lack of light seems to be less expressed as a constraining factor.

The relative importance of a ruderal strategy decreased along the temperature gradient, suggesting the larger impact of natural and anthropogenic disturbances (e.g. windthrows, pest infestations, drought stress and associated tree mortality, sleet (ice break), salvage logging) in high-altitude compared to lowland forests. Additionally, Picea abies sites were mostly characterized by competitive graminoids (e.g. grasses, such as Calamagrostis villosa or Deschampsia flexu$o s a$ ), which also exhibit substantial ruderal behaviour as they are able to spread after local canopy disturbance through means of extensive vegetative propagation.

Overall, tree layer SCA was recognized as an environmental factor with the highest number of significant associations with either floristic or trait composition (eight correlations in total). Another important characteristic related to forest stands was tree layer richness, which proved significant in five occasions, followed by mean annual temperature (four correlations). Amongst the other potential predictors, tree species composition, soil $\mathrm{pH}$, soil nitrogen content and soil clay content (all exhibiting three correlations in total) were also strong predictors for herb-layer vegetation composition. Given that the main environmental determinants of herb-layer composition were linked to stand characteristics (we did not include other potential factors, such as vertical structure, which has been shown to be deterministic for plant composition in mature forests; Dölle et al. 2017) and forest soil properties (but not accounting for litterlayer attributes; e.g. Mölder et al. 2008), appropriate forest management interventions should be applied to support the conservation of local site-adapted tree layer species composition, richness and structure without significantly impacting soil layers and consequently the preservation of disturbance-sensitive herbaceous species. Understanding the determinants of herb-layer composition and diversity provides a theoretical basis for sustainable management practices (Wei et al. 2020). Clearly, efforts to preserve biodiversity and promote long-term sustainability in temperate forests cannot ignore understory species (e.g. Šebesta et al. 2017).

In addition, the climatic signal evidenced in the significant effect of mean annual temperature and precipitation on floristic composition suggests that plant communities in temperate forests are likely sensitive to ongoing climate change, i.e. warming and drying (Amatangelo et al. 2014). Since functional composition largely reflects floristic composition, similar effects of future climate shifts can be expected for community trait patterns (Felsmann et al. 2018). As highlighted by Cubino et al. (2021), trait variation of understory plant communities at the continental scale is driven by macroclimate and soil factors and modulated by overstory canopy cover. All these factors (or their surrogates) were addressed also in our study. Such analyses further warrant the importance of assessing both biodiversity and functional responses to increase our understanding of the possible impact of global change on the herb layer (Depauw et al. 2019). Climate changes act as triggers for natural and anthropogenic forest disturbances. Based on a subset of the plots included in the present study, Kutnar et al. (2019) demonstrated that more disturbed sites showed larger temporal changes in species 
composition compared to less-disturbed sites, suggesting that forest disturbances caused significant compositional shifts over a 10-year period across Slovenian forest ecosystems.

Acknowledgements This study was performed as a part of the BioSoil Demonstration project and the Intensive Monitoring Programme in Slovenia (both part of the EU Programme ICP Forests). The research was funded by the Slovenian Ministry of Agriculture, Forestry and Food (JGS tasks $1 / 2$ and 1/3) and by the Slovenian Research Agency (research core funding No. P40107). J.K. was funded by the Slovenian Research Agency for his Young Researcher Programme (Contract No. 1000-180404). We would like to thank Primož Simončič, Mihej Urbančič, Daniel Žlindra, Polona Kalan, Marko Kovač, Matej Rupel and other colleagues from the Slovenian Forestry Institute for different types of assistance as well as many experts from the Slovenia Forest Service. We wish to thank two anonymous reviewers for their constructive comments on the previous version of this manuscript and Klemen Eler for his valuable suggestions regarding the statistical analyses. We are grateful to Philip Jan Nagel for the linguistic revision of the manuscript.

Funding The research was funded by the Slovenian Ministry of Agriculture, Forestry and Food (JGS tasks $1 / 2$ and 1/3) and by the Slovenian Research Agency (research core funding No. P40107). J.K. was funded by the Slovenian Research Agency for his Young Researcher Programme (Contract no. 1000-18-0404).

\section{Availability of data and material Not applicable.}

Code availability Not applicable.

\section{Declarations}

Conflict of interest The authors of this manuscript have no conflict of interest to declare.

Open Access This article is licensed under a Creative Commons Attribution 4.0 International License, which permits use, sharing, adaptation, distribution and reproduction in any medium or format, as long as you give appropriate credit to the original author(s) and the source, provide a link to the Creative Commons licence, and indicate if changes were made. The images or other third party material in this article are included in the article's Creative Commons licence, unless indicated otherwise in a credit line to the material. If material is not included in the article's Creative Commons licence and your intended use is not permitted by statutory regulation or exceeds the permitted use, you will need to obtain permission directly from the copyright holder. To view a copy of this licence, visit http://creativecommons.org/licenses/by/4.0/.

\section{References}

Amatangelo KL, Johnson SE, Rogers DA, Waller DM (2014) Trait-environment relationships remain strong despite 50 years of trait compositional change in temperate forests. Ecology 95:1780-1791. https://doi.org/10.1890/13-0757.1

Barkman JJ, Doing HS, Segal S (1964) Kritische Bemerkungen und Vorschläge zur quantitativen Vegetationsanalyse. Acta Bot Neerl 13:394-419

Bierzychudek P (1982) Life histories and demography of shadetolerant temperate forest herbs: a review. New Phytol 90:757-776. https://doi.org/10.1111/j.1469-8137.1982. tb03285.x

Bončina A, Rozman A, Dakskobler I, Klopčič M, Babij V, Poljanec A (2021) Gozdni rastiščni tipi Slovenije Vegetacijske, sestojne in upravljavske značilnosti. University of Ljubljana, Biotechnical Faculty, Department of Forestry and Renewable forest resources, Slovenia Forest Service, Ljubljana, Slovenia

Brunet J, Valtinat K, Mayr ML, Felton A, Lindbladh M, Bruun HH (2011) Understory succession in post-agricultural oak forests: habitat fragmentation affects forest specialists and generalist differently. For Ecol Manag 262:1863-1871. https://doi.org/10.1016/j.foreco.2011.08.007

Burton JI, Perakis SS, McKenzie SC, Lawrence CE, Puettmann KJ (2017) Intraspecific variability and reaction norms of forest understorey plant species traits. Funct Ecol 31:1881-1893. https://doi.org/10.1111/1365-2435.12898

Burton JI, Perakis SS, Brooks JR, Puettmann KJ (2020) Trait integration and functional differentiation among co-existing plant species. Am J Bot 107:628-638. https://doi.org/ 10.1002/ajb2.1451

Candeias M, Fraterrigo J (2020) Trait coordination and environmental filters shape functional trait distributions of forest understory herbs. Ecol Evol 10:14098-14112. https://doi.org/10.1002/ece3.7000

Canullo R, Starlinger F, Granke O, Fischer R, Aamlid D, Neville P (2016) Part VII.1: Assessment of Ground Vegetation. In: UNECE ICP Forests Programme Co-ordinating Centre (ed.): Manual on methods and criteria for harmonized sampling, assessment, monitoring and analysis of the effects of air pollution on forests. Thünen Institute of Forest Ecosystems, Eberswalde, 12 p. + Annex. http://www. icpforests.org/manual.htm. https://www.icp-forests.org/ pdf/manual/2016/ICP_Manual_2016_01_part07-1.pdf

Catorci A, Vitanzi A, Tardella FM (2011) Variations in CSR strategies along stress gradients in the herb layer of submediterranean forests (central Italy). Plant Ecol Evol 144:299-306. https://doi.org/10.5091/plecevo.2011.621

Chytrý M, Danihelka J, Kaplan Z, Wild J, Holubová D, Novotný P (2021) Pladias database of the Czech flora and vegetation. Preslia 93:1-87

Cools N, De Vos B (2016) Part X: Sampling and Analysis of Soil. In: UNECE ICP Forests Programme Coordinating Centre (ed) Manual on methods and criteria for harmonized sampling, assessment, monitoring and analysis of the effects of air pollution on forests. Thünen Institute of Forest Ecosystems, Eberswalde, Germany, 29 p + Annex [http:// www.icp-forests.org/manual.htm. www.icp-forests.org/ pdf/manual/2016/ICP_Manual_2016_01_part10.pdf

Cubino JP, Biurrun I, Bonari G, Braslavskaya T, Font X, Jandt U et al (2021) The leaf economic and plant size spectra of European forest understory vegetation. Ecography 44:1311-1324. https://doi.org/10.1111/ecog.05598 
Dalle Fratte M, Brusa G, Pierce S, Zanzottera M, Cerabolini BEL (2019) Plant trait variation along environmental indicators to infer global change impacts. Flora 254:113-121. https://doi.org/10.1016/j.flora.2018.12.004

De Cáceres M, Jansen F, Dell N (2020) Package "indicspecies" - Relationship between species and groups of sites. CRAN repository: https://cran.r-project.org/web/packages/ indicspecies/index.html

Depauw L, Perring MP, Landuyt D, Maes SL, De Lombaerde $\mathrm{BH}$ et al (2019) Light availability and land-use history drive biodiversity and functional changes in forest herb layer communities. J Ecol 108:1411-1425. https://doi.org/ 10.1111/1365-2745.13339

De Vries W, Reinds GJ, Deelstra HD, Klap JM, Vel EM (2000) Intensive Monitoring of Forest Condition in Europe: Technical Report 2000; UN/ECE EC: Brussels, Belgium; Geneva, Switzerland, p. 193. https://www.icp-forests.org/ pdf/TRLII2000.pdf

Dray S, Legendre P (2008) Testing the species traits-environment relationships: the fourth-corner problem revisited. Ecology 89:3400-3412. https://doi.org/10.1890/08-0349.1

Dray S, Dufour AB, Thioulouse J (2020) ade4: analysis of ecological data: exploratory and Euclidean methods in environmental sciences. https://cran.r-project.org/web/ packages/ade4/index.html

Dölle M, Petritan AM, Biris IA, Petritan IC (2017) Relations between tree canopy composition and understorey vegetation in a European beech-sessile oak old growth forest in Western Romania. Biologia 72:1422-1430. https://doi.org/ 10.1515/biolog-2017-0165

Dufrêne M, Legendre P (1997) Species assemblages and indicator species: the need for a flexible asymmetrical approach. Ecol Monogr 67:345-366. https://doi.org/10. 1890/0012-9615(1997)067[0345:SAAIST]2.0.CO;2

Durak T, Durak R (2021) Utilisation of traditional ecological plant classification systems to explain major dimensions of trait variation in herb layer of East Carpathians forests. Environ Exp Bot 185:104415. https://doi.org/10.1016/j. envexpbot.2021.104415

Eler K, Kermavnar J, Marinšek A, Kutnar L (2018) Short-term changes in plant functional traits and understory functional diversity after logging of different intensities: a temperate fir-beech forest experiment. Ann for Res 61:223-241. https://doi.org/10.15287/afr.2018.1192

Felsmann K, Baudis M, Kayler ZE, Puhlmann H, Ulrich A, Gessler A (2018) Responses of the structure and function of the understory plant communities to precipitation reduction across forest ecosystems in Germany. Ann for Sci 75:3. https://doi.org/10.1007/s13595-017-0681-7

Fick SE, Hijmans RJ (2017) WorldClim 2: New 1-km spatial resolution climate surfaces for global land areas. Int $\mathbf{J}$ Climat 37:4302-4315. https://doi.org/10.1002/joc.5086

Franklin JE (1988) Structural and functional diversity in temperate forests. In: Wilson EO (ed) Biodiversity. National Academy Press, Washington, DC, pp 166-175

Geiger R (1966) The climate near the ground. Harvard University Press, Cambridge, MA, USA

Gilliam FS (2007) The ecological significance of the herbaceous layer in temperate forest ecosystems. Bioscience 57:845-858. https://doi.org/10.1641/B571007
Grime JP (1977) Evidence for the existence of three primary strategies in plants and its relevance to ecological and evolutionary theory. Am Nat 111:1169-1194. https://doi. org/10.1086/283244

Hansen MC, Stehman SV, Potapov PV (2010) Quantification of global gross forest cover loss. Proc Natl Acad Sci USA 107:8650-8655. https://doi.org/10.1073/pnas.0912668107

Kermavnar J, Kutnar L (2020) Patterns of understory community assembly and plant trait-environment relationships in temperate SE European Forests. Diversity 12:91. https:// doi.org/10.3390/d12030091

Kermavnar J, Kutnar L, Marinšek A (2021) Disentangling the ecological determinants of species and functional trait diversity in herb-layer plant communities in European temperate forests. Forests 12:552. https://doi.org/10.3390/ f12050552

Kutnar L (2011) Diversity of woody species on forest monitoring plots in Slovenia. GozdVestn 69:271-278 (in Slovenian with English Summary)

Kutnar L, Veselič Ž, Dakskobler I, Robič D (2012) Typology of Slovenian forest sites according to ecological and vegetation conditions for the purpose of forest management. GozdVestn 70:195-214 (in Slovenian with English Summary)

Kutnar L, Nagel TA, Kermavnar J (2019) Effects of disturbance on understory vegetation across Slovenian Forest Ecosystems. Forests 10:1048. https://doi.org/10.3390/f10111048

Landuyt D, De Lombaerde E, Perring MP, Hertzog LR, Ampoorter E, Maes SL et al (2019) The functional role of temperate forest understorey vegetation in a changing world. Glob Change Biol 25:3625-3641. https://doi.org/ $10.1111 /$ gcb. 14756

Lavorel S, Grigulis K, McIntyre S, Williams NSG, Garden D, Dorrough $\mathrm{J}$ et al (2008) Assessing functional diversity in the field: methodology matters! Funct Ecol 22:134-147. https://doi.org/10.1111/j.1365-2435.2007.01339.x

Leuschner C, Lendzion J (2009) Air humidity, soil moisture and soil chemistry as determinants of the herb layer composition in European beech forests. J Veg Sci 20:288-298. https://doi.org/10.1111/j.1654-1103.2009.05641.x

Leuschner C, Meier IC (2018) The ecology of Central European tree species: trait spectra, functional trade-offs, and ecological classification of adult trees. Perspect Plant Ecol 33:89-103. https://doi.org/10.1016/j.ppees.2018.05.003

Márialigeti S, Tinya F, Bidló A, Ódor P (2016) Environmental drivers of the composition and diversity of the herb layer in mixed temperate forests in Hungary. Plant Ecol 217:549-563. https://doi.org/10.1007/s11258-016-0599-4

Marinšek A, Čarni A, Silc U, Manthey M (2015) What makes a plant species specialist in mixed broad-leaved deciduous forests? Plant Ecol 216:1469-1479. https://doi.org/10. 1007/s11258-015-0527-z

Martinčič A, Wraber T, Jogan N, Podobnik A, Turk B, Vreš B et al (2007) Mala Flora Slovenije: Ključ za določanje praprotnic in semenk; Tehniška založba Slovenije: Ljubljana, Slovenia, p. 967

McEwan RW, Muller RN (2011) Dynamics, diversity, and resource gradient relationships in the herbaceous layer of an old-growth Appalachian forest. Plant Ecol 212:1179-1191. https://doi.org/10.1007/s11258-0119896-0 
McKenzie D, Halpern CB, Nelson CR (2000) Overstory influences on herb and shrub communities in mature forests of western Washington, U.S.A. Can J for Res 30:1655-1666. https://doi.org/10.1139/x00-091

Mölder A, Bernhardt-Römermann M, Schmidt W (2008) Herblayer diversity in deciduous forests: raised by tree richness or beaten by beech? Forest Ecol Manag 256:272-281. https://doi.org/10.1016/j.foreco.2008.04.012

Muller RN (1978) The phenology, growth and ecosystem dynamics of Erythronium americanum in the northern hardwood forest. Ecol Monogr 48:1-20. https://doi.org/10. 2307/2937357

Oksanen J, Blanchet FG, Friendly M, Kindt R, Legendre P, McGlinn D (2019) Package 'vegan'-Community Ecology Package. https://cran.r-project.org/web/packages/ vegan/vegan.pdf

Pierce S, Negreiros D, Cerabolini BEL, Kattge J, Díaz S, Kleyer $M$ et al (2017) A global method for calculating plant CSR ecological strategies applied across biomes world-wide. Funct Ecol 31:444-457. https://doi.org/10.1111/13652435.12722

R Core Team (2018) R: a language and environment for statistical computing. Vienna, Austria. http://www.R-project. org/

Ramovs BV, Roberts MR (2005) Response of plant functional groups within plantations and naturally regenerated forests in southern New Brunswick, Canada. Can $\mathbf{J}$ for Res 35:1261-1276. https://doi.org/10.1139/x05-049

Raunkiaer C (1934) The life forms of plants and statistical plant geography; being the collected papers of C. Raunkiaer. Clarendon Press, Oxford, p 632

Schmidt M, Mölder A, Schönfelder E, Engel F, Schmiedel I, Culmsee H (2014) Determining ancient woodland indicator plants for practical use: a new approach developed in northwest Germany. Forest Ecol Manag 330:228-239. https://doi.org/10.1016/j.foreco.2014.06.043

Sercu BK, Moeneclaey I, Goeminne B, Bonte D, Baeten L (2021) Flowering phenology and reproduction of a forest understorey plant species in response to the local environment. Plant Ecol. https://doi.org/10.1007/s11258-02001104-2

Silvertown J, Franco M, Pisanty I, Mendoza A (1993) Comparative plant demography - relative importance of lifecycle components to the finite rate of increase in woody and herbaceous perennials. J Ecol 81:465-476. https://doi.org/ $10.2307 / 2261525$

Sipoš J, Chudomelova M, Vild O, Macek M, Kopecký M, Szabó $P$ et al (2020) Plant diversity in deciduous temperate forests reflects interplay among ancient and recent environmental stress. J Veg Sci 31:53-62. https://doi.org/10.1111/jvs. 12816

Suding KN, Lavorel S, Chapin FS III, Cornelissen JHC, Díaz S, Garnier E et al (2008) Scaling environmental change through the community-level: a trait-based response-andeffect framework for plants. Glob Change Biol
14:1125-1140. https://doi.org/10.1111/j.1365-2486.2008. 01557.x

Šebesta J, Maděra P, Řepka R, Matula R (2017) Comparison of vascular plant diversity and species composition of coppice and high beech forest in the Banat region, Romania. Folia Geobot 52:33-43. https://doi.org/10.1007/s12224-0169279-3

Tardella FM, Postiglione N, Bricca A, Cutini M, Catorci A (2019) Altitude and aspect filter the herb layer functional structure of sub-Mediterranean forests. Phytocoenologia 49:185-198

Ter Braak CJF (1987) The analysis of vegetation-environment relationships by canonical correspondence analysis. Vegetatio 69:69-77. https://doi.org/10.1007/BF00038688

Terwei A, Zerbe S, Mölder I, Annighöfer P, Kawaletz H, Ammer C (2016) Response of floodplain understory species to environmental gradients and tree invasion: a functional trait perspective. Biol Invasions 18:2951-2973. https://doi.org/10.1007/s10530-016-1188-0

Thrippleton T, Bugmann H, Kramer-Priewasser K, Snell RS (2016) Herbaceous understorey: an overlooked player in forest landscape dynamics? Ecosystems 19:1240-1254. https://doi.org/10.1007/s10021-016-9999-5

Tinya F, Kovács B, Bidló A, Dima B, Király I, Kutszegi G et al (2021) Environmental drivers of forest biodiversity in temperate mixed forests: a multi-taxon approach. Sci Total Environ 795:148720. https://doi.org/10.1016/j.scitotenv. 2021.148720

Urbančič M, Kutnar L, Kobal M, Žlindra D, Marinšek A, Simončič P (2016) Soil and vegetation characteristics on Intensive Monitoring Plots of forest ecosystems. GozdVestn 74:3-27 (in Slovenian with English Summary)

Wei L, Archaux F, Hulin F, Bilger I, Gosselin F (2020) Stand attributes or soil micro-environment exert greater influence than management type on understory plant diversity in even-aged oak high forests. For Ecol Manag 460:117897. https://doi.org/10.1016/j.foreco.2020.117897

Weigel R, Gilles J, Klisz M, Kreyling J (2019) Forest understory vegetation is more related to soil than to climate towards the cold distribution margin of European beech. J Veg Sci 30:746-755. https://doi.org/10.1111/jvs. 12759

Whigham DE (2004) Ecology of woodland herbs in temperate deciduous forests. Annu Rev Ecol Evol Syst 35:583-621. https://doi.org/10.1146/annurev.ecolsys.35.021103. 105708

Willner W, Di Pietro R, Bergmeier E (2009) Phytogeographical evidence for post-glacial dispersal limitation of European beech forest species. Ecography 32:1011-1018. https://doi. org/10.1111/j.1600-0587.2009.05957.x

Wraber M (1969) Pflanzengeographische Stellung und Gliederung Sloweniens. Vegetatio 17:176-199

Publisher's Note Springer Nature remains neutral with regard to jurisdictional claims in published maps and institutional affiliations. 